\title{
HEMOLYTIC DISEASE IN THE NEWBORN - HISTORY AND PREVENTION IN THE WORLD AND THE CZECH REPUBLIC
}

\author{
Jiri Santavy \\ Department of Medical Genetics and Fetal Medicine, Faculty of Medicine, Palacky University Olomouc, Czech Republic \\ E-mail: jiri.santavy@fnol.cz
}

Received: February 2, 2010; Accepted: May 4, 2010

Key words: Hemolytic disease/Newborns/History/Czech Republic

Background. Hemolytic disease in the newborn with its typical signs and poor prognosis has been known for centuries. Historically it can be divided into three pathological states which are fetal hydrops (hydrops fetus universalis), neonatal jaundice (icterus neonati gravis familiaris) and fetal anemia (anemia neonati). Almost 70 reports with quite accurate descriptions were found up to the end of $19^{\text {th }}$ century. The patho physiological basis of the condition began to be studied at the beginning of the last century and the development of our knowledge is an example of the cooperation between pathologists, pediatricians, hematologists and later, obstetricians, immunologists and geneticists. Despite all the advances in this field it remains a serious disease up to this time. It is not managed successfully in all cases and despite successful immunological prophylaxis there are cases when we need to administer intrauterine transfusion based on the information received by dopplerometric measurement of arteria cerebri perfusion and fetal blood sampling.

Methods. Review of lover cited literature.

Conclusion. The history of the hemolytic disease in the newborn, its condition and approaches to it has not been recently compiled in the Czech Republic.

\section{INTRODUCTION}

Hemolytic disease of the newborn with its typical signs and poor prognosis has been known for centuries. Its path physiological basis began to be studied at the beginning of the last century and the development of our knowledge is an example of the cooperation between pathologists, pediatricians, hematologists and later obstetricians, immunologists and geneticists. Despite all the advances in this field it remains a serious condition up to this time. It is not managed successfully in all cases and despite successful immunological prophylaxis with anti-D-gamaglobulin there are frequent instances when we need to administer intrauterine transfusion based on the information received by dopplerometric measurement of arteria cerebri perfusion and fetal blood sampling. The history of this condition and the approaches to it has not been recently compiled in the Czech Republic.

When we search for the initial interest in hematological disease of the newborn then we need to historically divide it into three pathological states which are fetal hydrops (hydrops fetus universalis), neonatal jaundice (icterus neonati gravis familiaris) and fetal anemia (anemia neonati).

The first recorded description of the condition originates probably from Hippocrates. There is a mention of fetus carnosus, which is thought by medical historians to represent fetal hydrops. The publication by Ballanty from 1902 (ref. ${ }^{1}$ ) is very helpful in the study of this subject. He found characteristic features of this type of hydrops in the literature as early as 1614 and found almost 70 more or less accurate descriptions of this pathological state of the newborn up to 1892. The cause of this frequency was almost certainly its omissible exceptionality, with the striking look of a hydropic newborn complete with an extensive ascites which could reach up to $500 \mathrm{ccm}$ and was always a birth obstruction. To overcome this it was necessary to perform paracenthesis or more often an embryotomy to save the life of the woman. All these reports are case studies - more or less curiosities. The first descriptive work was that of Schridde from 1910 (ref. $^{2}$ ) which reviewed the condition from the point of view of morphology and partly pathogenesis. He suspected, quite correctly, that the characteristic extramedular hematopoesis in the spleen and liver and the increased number of immature erythrocytes were a reaction to tissue anemia. The actual name of this phenomenon - erythroblastosis - which is used to this day is two years younger and was coined by Rautmann ${ }^{3}$. However, he thought the 'proliferation' of the hematopoietic tissue to be the primary pathology - hence the term.

Neonatal jaundice (icterus neonati gravis) was described in 1884 by Aschby, who also for the first time documented the recurrence of the condition within one family. Other authors, who however merely described the condition without any attempt to explain it, were Blomfield in 1901 and Lagrez in 1904. In 1908 Pfanennsteil made an attempt to include the condition to the group of neonatal jaundices. Characteristic microscopic changes were first described by Buchan a Comrie in 1909 (ref. $^{4}$ ). In 1921 Gierke $^{5}$ made a connection between the typical jaundice and hydrops fetus universalis, which was missing until then. As this author also thought the proliferation of hematopoietic tissue to be the cause of 
the condition, this term was used for both conditions. In 1926 Plaut and Bullard described the occurrence of both types of the condition in one family and their observations were quickly followed by more cases. A conclusion of a sort was a description of both forms of the condition in one fetus in 1931 by Gierke ${ }^{6}$, who had had a long term interest in the condition. It was his study which enabled confirmation of a common pathogenesis. The same conclusion was made by a working party of Diamond et $\mathrm{al}^{7}$.

The third pathological state is anemia neonati. This was probably first studied by the Swiss pediatrician Eclin in 1919 in a family with a case of icterus neonati gravis in a neonate with fatal outcome. During an investigation of a blood sample, erythroblasts were seen which led to the suspicion of a common cause. This was confirmed in 1933 by Mackay and O'Flynt by a description of all three forms of the disease in one family. Hellman and Hertig $^{8}$ engaged in more detailed hematological studies and described anemia in at least $80 \%$ of cases and also described the clinical cause of the jaundice with its emergence shortly after birth. Kernicterus - 'dark yellow, usually sharply demarcated coloring of some gray matter segments usually at the base of the brain' was first thought to be a separate finding accompanying significant jaundice. The author of the term is Schmorl.

In the period between the world wars the number of published observations increased, indicating that it was not as previously thought, a mere curiosity but a quite common obstetric pathological state with serious consequences. A large number of studies were published at the time. Worth a mention is undoubtedly a study by Darrow ${ }^{9}$ which for the first time on the basis of publications on fetal erythroblastosis formulated a possibility of a serological immune reaction of antigen and an antibody. $\mathrm{He}$ suspected that the immunization of the maternal blood was caused by fetal blood and antibodies arising in the maternal organism which then reached the fetus either transplacentally or later through colostrum. Darrow concluded that the carrier of the foreign antigen was fetal hemoglobin which was molecularly different from maternal hemoglobin, because no abnormalities could be found from studying the blood markers. The recognition of the basis of the condition was made in 1940, by Landsteiner and Wiener ${ }^{10}$ who described the Rh factor and by Levine a Stetson ${ }^{11}$ who published its direct application to erythroblastosis. The same authors went on to discover anti Rh serum, which agglutinated about $70 \%$ of blood samples of Caucasian origin. Soon after that Wiener and Sonn ${ }^{12}$ discovered another human anti Rh serum, which agglutinated the erythrocytes of $30 \%$ of the population. At the same time they confirmed that the discovered antigen was inherited in a Mendelian fashion and was determined by an alelomorphic gene. The same problem was concurrently investigated - independently due to the war - by a group of British authors Race, Taylor, Cappell, and McFarlan, Boormann and Dodd (ref. ${ }^{13-16}$ ). The research then gained pace in the United States and also in Britain, while in other parts of Europe it slowed down.

Scientists in the former Czechoslovakia became interested in the subject quite early and were probably second only to Great Britain ${ }^{17,18}$. As soon as 1944 it was possible to investigate the Rh system in the country. The method was developed by Raska ${ }^{19}$, who gained access to Macaque rhesus monkeys through Vinohrady vivarium and was producing a specific guinea pig serum. In a short time the authors focused human sera which contained anti-Rh agglutinins formed under pathological conditions. At the same time the pathologically-etiological question began to be addressed. In 1940 while investigating the causes of perinatal death, which included erythroblastosis, Sikl and Raska ${ }^{20}$ realized that: 'It will be impossible to delineate the disease exactly until a missing causal pathological basis will be found'. He welcomed the possibility of following up the new discoveries in the field of serology and started his cooperation with Raska. In 1947, both authors published a sizable study, the first one on the subject in Czechoslovakia, called Fetal erythroblastosis which was published by the Association of Czech Physicians. It is interesting that they considered the disease in the context of the quality of prenatal care and the then widely discussed eugenics. They demonstrated their farsightedness in the final chapter: "We want to believe, that the future success of biochemistry following the serological discoveries will enable an effective prevention of fetal erythroblastosis". Another publication in Czechoslovakia that dealt with the same problem was the Hemolytic disease of newborn, which was published in 1970 by the publishing house Osveta Martin by the authors A. Pontuch, M. Hrubisko and J. Michalicková ${ }^{21}$. An enormous number of new studies in the field were accumulated which called for a new complex literary overview aimed at the Czechoslovak medical community. The groundbreaking work was the publication by Race and Sangerova in 1968 (ref. ${ }^{22}$ ), who were concentrating on a genetic basis following the immunogenetic studies of Ceppellini 1959 ( ref. $^{23}$ ) and the results of biochemical analysis of antigens of mucoid nature. The interest of scientists was directed towards other antigens, for example $\mathrm{M}$ and $\mathrm{N}$, which were discovered by Landsteiner and Levine in 1927 (ref. ${ }^{24}$ ). While working with heteroimmune sera it was shown that their efficacy was much lower and that only very rarely were they a cause of immunization, like other systems. Schwenzer et al. in 1958, Hellman and Hertig (ref. ${ }^{25,26}$ ) studied the remaining levels of antibodies in maternal circulation and showed the difficulties of their utilization in current pregnancy. Polacek in 1961 (ref. ${ }^{27}$ ) attempted to establish a clinical classification based on antibody level. Diagnostic methods continued to improve and a notable landmark is the work by Kleinhauer, Braun and Betke in 1957 (ref. ${ }^{28}$ ) which claimed that fetal erythrocytes containing fetal hemoglobin could be found in maternal blood.

The term fetal transfusion and its definition as a "Main cause of sensitization" is however older and was coined by Levin in 1941. Keenan and Pearse in 1963 (ref. ${ }^{29}$ ) studied it in greater depth and found it in $7 \%$ of fetal erythrocytes before delivery and 19\% after delivery. Direct association was then studied and described by Pfleiderer in 1965 $\left(\right.$ ref. $^{30}$ ) who was the first to point out immunization by miscarriages of pregnancies lasting over four months, 
Kristeller maneuver, caesarean section, manual extraction of the placenta and transabdominal fetal expression.

Efforts to prevent hemolytic disease of the newborn date to the oldest times, when empirical approaches were used, often with very doubtful results. Possibilities improved when blood groups were discovered (Landsteiner in 1901, Jansky in 1907 and Moss in 1910) ) $^{31,32}$ and following the important work by Levin and Stetson in 1939 (ref. ${ }^{33}$ ) and Schriedde ${ }^{34}$, who elucidated the cause of hemolytic disease in newborns as a condition caused by an immunization of mother by blood cells of the fetus. After the war the principals of blood transfusion were developed and it was possible to test for all the main blood groups and also the Rh factor. In 1966 Bickenbach $^{35}$ studied the sensitization of mothers in pregnancy and the function of the placenta. He correctly identified the fetoplacental barrier but as a preventative measure suggested an "Administration of substances with estrogenic properties, vitamins C, K and P”, which ought to prevent the passage of antigen into the bloodstream of the mother, and vitamin $E$, which ought to prevent the degenerative changes in the chorion of the placenta. The following years were very productive with many new discoveries. In 1970 Pontuch $^{36}$ stated the main preventative measures which are valid to this day:

a) prevention of crossing of fetal erythrocytes into maternal circulation and antibodies in the opposite direction

b) the blockage of antibody production in maternal circulation

c) prevention of sensitization of maternal erythrocytes with fetal erythrocytes.

d) prevention of $\mathrm{Rh}$ sensitization by anti-D administration

e) intrauterine transfusion in pregnancy.

Even though the measures fulfill today's criteria, their execution was more problematic. It consisted of administration of corticoids between the $11^{\text {th }}$ and $14^{\text {th }}$ week of gestation together with depot application of ACTH, a diet rich in proteins with low salt content, administration of bismuth, antihistamines or doses of $\mathrm{Rh}$ and $\mathrm{ABO}$ compatible blood administered in the second half of pregnancy. These were thought to decrease the production of antibodies.

The end of the sixties saw the rise of the prevention of $\mathrm{Rh}$ sensibilization by an administration of anti-D immunoglobulin. The basic idea is identical with the current aim to administer anti D serum or later anti-D globulin to Rh negative women immediately after the first childbirth and thus eliminate fetal erythrocytes from the maternal circulation preventing isoimmunization. The clinical application was preceded by numerous clinical experiments. These were conducted by a group of British authors Finn in 1961 (ref. $^{37}$ ), Woodrow in 1965 (ref. ${ }^{38}$ ) and also by an American group Freda, Gorman and Pollack in 1956 (ref. ${ }^{39}$ ) and involved several European institutions. They laid the immunological foundations of the modern prevention of hemolytic disease of the newborn. Together with the German scientists Schneider and Preisler in 1967 $\left(\right.$ ref. $^{40}$ ) they proved that administration of anti-D cannot effect already present sensibilization. The originally fractional knowledge continued to grow and in the seventies indications for selective prevention were specified. However up to this time the protocols varied in different departments in Czechoslovakia and abroad (Zizka and Calda $)^{41}$.

A relatively older method of prevention is intrauterine transfusion into the abdominal cavity of the fetus. This method was described for the first time by Liley in 1961 (ref. $^{42}$ ) and Queenan et al. ${ }^{43}$. He utilized the knowledge that erythrocytes instilled into the abdominal cavity migrate into the blood stream of the fetus within about one week. The localization of the fetus in the uterus was achieved by amniography. A radio contrast agent was introduced into the amniotic cavity, where possible extraplacentally. The fetus swallowed it and about eight hours later under the X-ray guidance $75-185 \mathrm{ml}$ of $\mathrm{O} \mathrm{Rh}$ negative erythrocytal mass was injected into the abdominal cavity of the fetus. In Czechoslovakia this procedure was for the first time performed by Prochazka and Richter in 1966 (ref. $\left.{ }^{44}\right)$.

Prenatal ultrasonography underwent rapid development from the beginning of the seventies. The method enabled detailed examination of the morphology of the fetus and also the execution of invasive procedures, such as amniocentesis, Cordocenthesis, intrauterine intravasal transfusion and chorionic villus sampling. In the Czech Republic this method was developed mainly by Krikal et al. in 1983 (ref. ${ }^{45}$ ) and Santavy et al. in 1993 and 1995 $\left(\right.$ ref. $\left.^{46,47}\right)$. The original Liley ${ }^{48}$ curve used for estimation of bilirubinoids in amniotic fluid can be used only from the $28^{\text {th }}$ week of gestation. Bowman and Queens's modification (1993) (ref. $\left.{ }^{49}\right)$ allowed its application from the $15^{\text {th }}$ week of gestation and in that form the method was by many departments until recently.

A direct approach to fetal circulation was achieved for the first time in 1964 using hysterotomy (Freda and Adamson $^{50}$, Preisler and Schneider ${ }^{51}$ ). The development of optic fibers allowed visualization and venipuncture of placental vessels - Valenti in 1973 (ref. ${ }^{52}$ ), Hobbins and Mahoney in 1974 (ref. ${ }^{53}$ ) - and later utilizing a fetoscopy of umbilical vessels (Rodeck a Campbell in 1979) (ref. ${ }^{54}$ ). Apart from other unused means of access such as via fetal liver or the intrahepatic vein it is necessary to mention intracardiac access developed by Antsaklis in 1992 $\left(\right.$ ref. $^{55}$ ). From 1982, a transabdominal ultrasound-controlled venipuncture of the umbilicus became an unwritten standard - optimally in the point of its placental insertion (Bang et al. 1982, Daffos et al. 1983) ${ }^{56,57}$. Calda et al. in 1991 (ref. $^{58}$ ) were the first to report this procedure in the Czechoslovakia.

The works of Mari et al. in 2000 (ref. ${ }^{59,60}$ ) were a groundbreaking discovery in the field of hemolytic disease of the newborn. It focused on the possibility of noninvasive dopplerometric determination of fetal anemia. This method was then worked out in greater detail by Zimmerman in 2002 (ref. ${ }^{61}$ ) and confirmed the possibility of establishing the degree of Alloimmunization of fetal red blood cells by systolic velocimetry measured in the arteria cerebri media of the fetus. This method reduced the 
number of prenatal invasive procedures and improved the prognosis of children of aluminized women. In the Czech Republic the method was developed and introduced into clinical practice by Lubusky in 2004 (ref. ${ }^{62}$ ).

The problems of hemolytic disease of the newborn are still topical and new discoveries keep modifying our approach to it. When looking at its history we could concentrate on cell biology, introduction of new methods of DNA analysis, creation of vaccines or the first experimental results in immunological and gene therapy. Most of these methods are being intensively researched but they are beyond the scope of this article.

\section{REFERENCES}

1. Ballanty JW. Manual of antenatal pathology and hygiene: the foetus. Green \& Sons; 1902.

2. Schriedde H. Weitere Untersuchungen über die Körnelungen der Plasmazellen. Centralbl Allg Pathol Anat 1905.

3. Rautmann H. Über Blutbildung bei fetaler allgemeiner Wassersucht. Beitr Pathol Anat 1912.

4. Buchan AH, Comrie JD. Four cases of congenital anemia with jaundice and enlargement of the spleen. J Path \& Bact 1909.

5. Gierke E. Über granulierend produktive Myokarditis mit Regeneration von Herzmuskelfasern. Beitr Pat Anat 1921.

6. Gierke E. Über fetale Krankheiten. J Mol Med 1931.

7. Diamond LK, Blackfan KP, Baty JM. Erythroblastosis fetalis and its association with universal edema of the fetus, icterus gravis. J Pediatr 1932.

8. Hellman LM, Hertig AT. Erythoblastosis. Amer J Obstetr Gynecol 1938; 36:137.

9. Darrow RR. Icterus gravis (erythroblastosis neonatorum, examination of etiologic considerations). Arch Pathol 1938; 25:378.

10. Landsteiner K, Wiener AS. Proc Soc Exp Biol a Med 1940; 43:223.

11. Levine P, Stetson RE. An unusual case of intragroup agglutination. J Amer Med Ass 1939; 113:126-127.

12. Wiener AS, Sonn EB. Genetics 1943; 28:157.

13. Race RR, Taylor GL, Boorman KE, Dodd BE. Nature 1943; 152:563.

14. Race RR, Taylor GL, Cappell DF, Mc Farlane MN. Nature 1944; 153:52.

15. Boormann RE, Dodd BE. J Path \& Bact 1943; 55:329.

16. Cappell DF. Brit M J 1945; 400.

17. Comrie JD. History of Medicine. University Press 1910.

18. Hrubiško M, Hule V. Hematológia a transfúzi krvi. Obzor, Martin; 1966 a Osveta; 1970.

19. Raška K. Serologické vyšetřování krví ve sporech o určování otcovství. Praha; 1944.

20. Šikl K, Raška K. Fetální erythroblastosa. Nakl. Spolek českých lékařů, Praha; 1947.

21. Pont'uch A, Války J. Possible isoimmunization following legal interruptions of pregnancy. Čs Gynek 1970; 35(6): 357-8.

22. Race RR, Sanger R. Blood groups in man. Blackwell, Oxford; 1968.

23. Ceppellini R. Physiological genetics of human factors. Biochemistry of Human

24. Landsteiner K, Levine P. Further observations on individua differences of human blood. Proc Soc exp Biol N. Y. 1927; 24:941-942.

25. Schwenzer AW, Hellman LM, Hertig AT. Das Grerinnungssystem unter der Geburt. Am J Pathol 1938.

26. Hellman LM, Hertig AT. Pathological changes in the placenta associated with erythroblastosis of the fetus. Amer J Pathol 1938; 14 , III.

27. Polacek K, Hajek M. Haemolytic disease of the newborn control of replacement of the erythrocytes by the means of foetal haemoglobin. Rev Czech Med 1961; 7:263-270.
28. Kleinhauer K, Braun E, Betke K. Demonstation von fetalen Haemoglobin in den Erytrozyten eines Blutausstrichs. Klin Wschr 1957; 35: 637-640.

29. Keenan H, Pearse WH. Transplacental transmission of fetal erytrocytes. Amer J Obstet Gynecol 1963; 86:1096.

30. Pfleiderer A. Die Geburtenfolge bei in Rh System sensibilisierten Frauen. Geburtsh u Frauenheilk 1965; 25:1177.

31. Janský J. Hematologické studie u psychotiků. Sborník klinický 1907; 8:85

32. Moss WL. Studies in iso-agglutinins. Bull Johns Hopk Hosp 1910; 21:63.

33. Levine P, Stetson RE. An unusual case of intragroup agglutination. J Amer Med Ass 1939; 113:126-127.

34. Schriedde H. Studien und Fragen zur Entzündungslehre. Gustav Fischer Verlag, 1910.

35. Bickenbach, Martius G. Preventive examinations during pregnancy. Arztl Fortbild (Berl) 1965; 54:149-65.

36. Pontuch A, Hrubiško M, Michalíčková J. Hemolytická choroba novorodevcov. Osveta, Martin; 1970.

37. Finn R, Sheppard PM, Lehane D, Kulke W. Experimental studies on the prevention of Rh hemolytic disease. Brit Med J 1961; 1486:490.

38. Woodrow JC at al. Prevention of Rh-Haemolytic Disease. Brit Med J 1965; 5430:279-283.

39. Freda VJ, Adamsons K. Exchange transfusion in utero. Amer J Obstet Gynecol 1964; 89:817.

40. Schneider J, Preisler O. Die profylaxe der Thesis-sensibilisierung mit Immunoglobulin anti-D. Ärztl Forschung 1967; 21:11.

41. Žižka Z, Calda P. Aktuální otázky sledování a léčby těžké erytrocytární aloimunizace. Mod Gyn Porod 2002; 2:241-250.

42. Liley AW. Liquor amnii analysis in the management of the pregnancy complicated by thesis sensitiation. Amer J Obstet Gynecol $1961 ; 82: 1354$

43. Queenan JT et al. Deviation in the amniotic fluid optical density at a wave lenghtof $450 \mathrm{~nm}$ in Rh-imunized pregnancies from 14 to 40 week's gestation: A proposal for clinical management. Am J Obstet Gynecol 1993;168:1370.

44. Procházka M, Richter J. Intrauterinní transfuze plodu př̀ Rh inkompatibilitě. Čs Gynek 1967; 32: 119.

45. Kř̌ikal Z, Pohanka J, Šantavý J, Látalová E. Význam amniocentézy při sledování rizikového těhotenství. Čs Gynek 1983; 48: 7, 48.

46. Šantavý J, Křikal Z, Prášilová J, Doležal L. Prenatální diagnostika VVV ultrazvukovým přistrojem. Čs Gynek 1993; 48: 41.

47. Šantavý J, Polák P, Župková H. Kordocentéza jako podmínka intrauterinní transfuze u Rh inkompatibility plodu. Gynekolog 1995; 4:132-137.

48. Liley AW. The use of amniocentesis and fetal transfusion in erytroblastosis fetalis. Pediatrics $1965 ; 35: 836$.

49. Bowman JM, Pollock JM, Manning FA. Maternal Kell blood group alloimunization. Obstet Gynecol 1992; 79:239.

50. Freda VJ, Adamsons K. Exchange transfusion in utero. Amer J Obstet Gynecol 1964; 89: 817.

51. Preisler O, Schneider J. Versuche die Sensibilisierung rh-negativen Frauen durch antikörperhaltige Seren zu verdinen. Geburtsh u. Frauenheilk 1964; 24: 124-131

52. Valenti C. Endoamnioscopy and fetal biopsy: a new technique. Am J Obstet Gynecol 1972; 114(4): 561-4.

53. Hobbins JC, Mahoney MJ. In utero diagnosis of hemoglobinopathies. Technic for obtaining fetal blood. N Engl J Med 1974; 9: 290(19):1065-7.

54. Rodeck $\mathrm{CH}$, Campbell S. Umbilical-cord insertion as source of pure fetal blood for prenatal diagnosis. Lancet 1979; 9,1(8128):1244-5.

55. Antsaklis AI, Papantoniou NE, Mesogitis SA et al. Cardiocentesis: an alternative method of fetal blood sampling for prenatal diagnosis of hemoglobinopathies. Obstet Gynecol 1992; 79:633-630.

56. Bang J, Bock JE, Trolle D. Ultrasound-guided fetal intravenous transfusion for severe rhesus haemolytic disease. Br Med J 1982; (Clin Res Ed) 6: 284(6313): 373-374.

57. Daffos F, Capella-Pavlovsky M, Forestier F. Am J Obstet Gynecol 1983; 15; 146(8): 985-7. 
58. Calda P, Žižka Z, Zlatohlávková B et al. Diagnostika a léčba erytrocytární alloimunizace v těhotenství. Čs Gynek 1998; 63:170174.

59. Genetics. Churchill, London; 1959;242-261.

60. Mari G. and the Collaborative Group for Doppler Assesment of the Blood Velocity in Anemic Fetuses. Noninvasive diagnossis by Doppler Ultrasonography of fetal anemie due to maternalred cell alloimunisation. N Eng J Med 2000; 9:342.
61. Zimmerman R, Carpenter RJ, Durig P et al. Longitudinal measurement of peak systolic velocity the fetal middle cerebral artery for monitoring pregnancies complicated by red cell alloimunisation: a prospective multicentre trial. Brit J Obstet Gynecol 2002; 109:746-752.

62. L’ubušký M, Procházka M, Šantavý J, Machač Š, Míčková I. Dopplerometrie při posouzení fetální anémie. Čs Gynek 2004; 69(4):316-320. 
